\title{
Longbasaba Glacier recession and contribution to its proglacial lake volume between 1988 and 2018
}

\section{Article}

Cite this article: Wei J, Liu S, Wang X, Zhang Y, Jiang Z, Wu K, Zhang Z, Zhang T (2021). Longbasaba Glacier recession and contribution to its proglacial lake volume between 1988 and 2018. Journal of Glaciology 67(263), 473-484. https://doi.org/10.1017/ jog.2020.119

Received: 18 June 2020

Revised: 26 December 2020

Accepted: 29 December 2020

First published online: 28 January 2021

\section{Key words:}

Glacier hazards; glacier mass balance; glacier monitoring; ice velocity

\section{Author for correspondence:}

Junfeng Wei,

E-mail:weijunfeng@hnust.edu.cn (c) The Author(s), 2021. Published by Cambridge University Press. This is an Open Access article, distributed under the terms of the Creative Commons Attribution licence (http://creativecommons.org/licenses/by/4.0/), which permits unrestricted re-use, distribution, and reproduction in any medium provided the original work is properly cited.

\section{Junfeng Wei ${ }^{1} \mathbb{D}^{0}$, Shiyin $\mathrm{Liu}^{2,3} \mathbb{B}^{-}$, Xin Wang ${ }^{1}$, Yong Zhang ${ }^{1}$, Zongli Jiang ${ }^{1}$,} Kunpeng $\mathrm{Wu}^{2,3}$, Zhen Zhang ${ }^{4}$ and Te Zhang ${ }^{1}$

\begin{abstract}
${ }^{1}$ Hunan Provincial Key Laboratory of Geo-Information Engineering in Surveying, Mapping and Remote Sensing, Hunan University of Science and Technology, Xiangtan 411201, China; ${ }^{2}$ Institute of International Rivers and Eco-Security, Yunnan University, Kunming 650091, China; ${ }^{3}$ State Key Laboratory of Cryospheric Science, Northwest Institute of Eco-Environment and Resources, Chinese Academy of Sciences, Lanzhou 730000, China and ${ }^{4}$ School of Geomatics, Anhui University of Science and Technology, Huainan 232001, China
\end{abstract}

\section{Abstract}

During the last few decades, the lake-terminating glaciers in the Himalaya have receded faster than the land-terminating glaciers as proglacial lakes have exacerbated the mass loss of their host glaciers. Monitoring the impacts of glacier recession and dynamics on lake extent and water volume provides an approach to assess the mass interplay between glaciers and proglacial lakes. We describe the recession of Longbasaba Glacier and estimate the mass wastage and its contribution to the water volume of its proglacial lake. The results show that the glacier area has decreased by $3 \%$ during $1988-2018$, with a more variable recession prior to 2008 than in the last decade. Longbasaba Lake has expanded by $164 \%$ in area and $237 \%$ in water volume, primarily as a result of meltwater inflow produced from surface lowering of the glacier. Over the periods 1988-2000 and 2000-18, the mass loss contributed by glacier thinning has decreased from 81 to $61 \%$ of the total mass loss, accompanied by a nearly doubled contribution from terminus retreat. With the current rate of retreat, Longbasaba glacier is expected to terminate in its proglacial lake for another four decades. The hazard risk of this lake is expected to continue to increase in the near future because of the projected continued glacier mass loss and related lake expansion.

\section{Introduction}

During the last few decades, an average mountain surface air temperature warming rate of $0.3 \pm 0.2^{\circ} \mathrm{C}$ per decade was detected across western North America, Europe and High Mountain Asia, which is higher than the global warming rate of $0.2 \pm 0.1^{\circ} \mathrm{C}$ per decade (IPCC, 2018). In response to rapid climate warming, the mass loss of global mountain glaciers, which are distinct from the Greenland and Antarctic ice sheets, contributed $27 \pm 22 \mathrm{~mm}$ to the global mean sea-level rise from 1961 to 2016, increasing by 30\% from 1986-2005 to 2006 -15 (Zemp and others, 2019). The mean mass balance of the Himalayan glaciers was $-0.25 \pm 0.09 \mathrm{~m}$ water equivalent (w.e.) $\mathrm{a}^{-1}$ over the period of 1974-2000, becoming more negative $\left(-0.39 \pm 0.12 \mathrm{~m}\right.$ w.e. $\left.\mathrm{a}^{-1}\right)$ between 2000 and 2015 (King and others, 2019). The mass loss of the lake-terminating glaciers was greater than that of the land-terminating glaciers (Carrivick and Tweed, 2013; Fujita and Sakai, 2014; Song and others, 2017; Begam and Sen, 2019; Brun and others, 2019; Tsutaki and others, 2019; Wu and others, 2019; Zhang and others, 2019; Andreassen and others, 2020; Watson and others, 2020). Across the Himalayan regions during the period 1974-2000, geodetic measurements indicate a mean mass loss of $-0.32 \pm 0.12 \mathrm{~m}$ w.e. $\mathrm{a}^{-1}$ for the lake-terminating glaciers, which was more negative than the value for the land-terminating glaciers $\left(-0.23 \pm 0.09 \mathrm{~m}\right.$ w.e. $\left.\mathrm{a}^{-1}\right)$ (King and others, 2019). Furthermore, the difference in the mass wastage between the two types of glaciers $\left(0.09 \mathrm{~m}\right.$ w.e. $\mathrm{a}^{-1}$ during $\left.1974-2000\right)$ doubled to $0.18 \mathrm{~m}$ w.e. $\mathrm{a}^{-1}$ in the period $2000-15$, with mean mass budgets of $-0.55 \pm 0.12$ and $-0.37 \pm 0.12 \mathrm{~m}$ w.e. $\mathrm{a}^{-1}$ for the lake-terminating and land-terminating glaciers, respectively (King and others, 2019).

The moraine dams of proglacial lakes are susceptible to failure via overtopping and piping trigger mechanisms (Richardson and Reynolds, 2000; Nie and others, 2018). In 1964, the Cirenmaco Lake moraine dam collapsed due to piping, which caused a glacial lake outburst flood (GLOF) (Yamada and Sharma, 1993). The failure of the same proglacial lake occurred again in 1981, directly triggered by a passage appearing $20-30 \mathrm{~m}$ below the water level within the moraine dam (Xu, 1988). Among the 1348 GLOFs recorded worldwide, more than 120 events occurred at moraine-dammed lakes (Carrivick and Tweed, 2016). In the Chinese Himalaya, 329 moraine-dammed lakes were detected using remotely sensed data, with an average area expansion rate of $25.11 \%$ from the 1990 s to the 2010 s, and $35 \%$ of these lakes were identified as potentially dangerous glacial lakes (Wang and others, 2015).

Longbasaba Lake is a typical moraine-dammed proglacial lake in the central eastern Himalaya with a high outburst risk and it has experienced dramatic expansion over recent decades (Yao and others, 2012b; Wang and others, 2016). Due to the significant retreat of the 

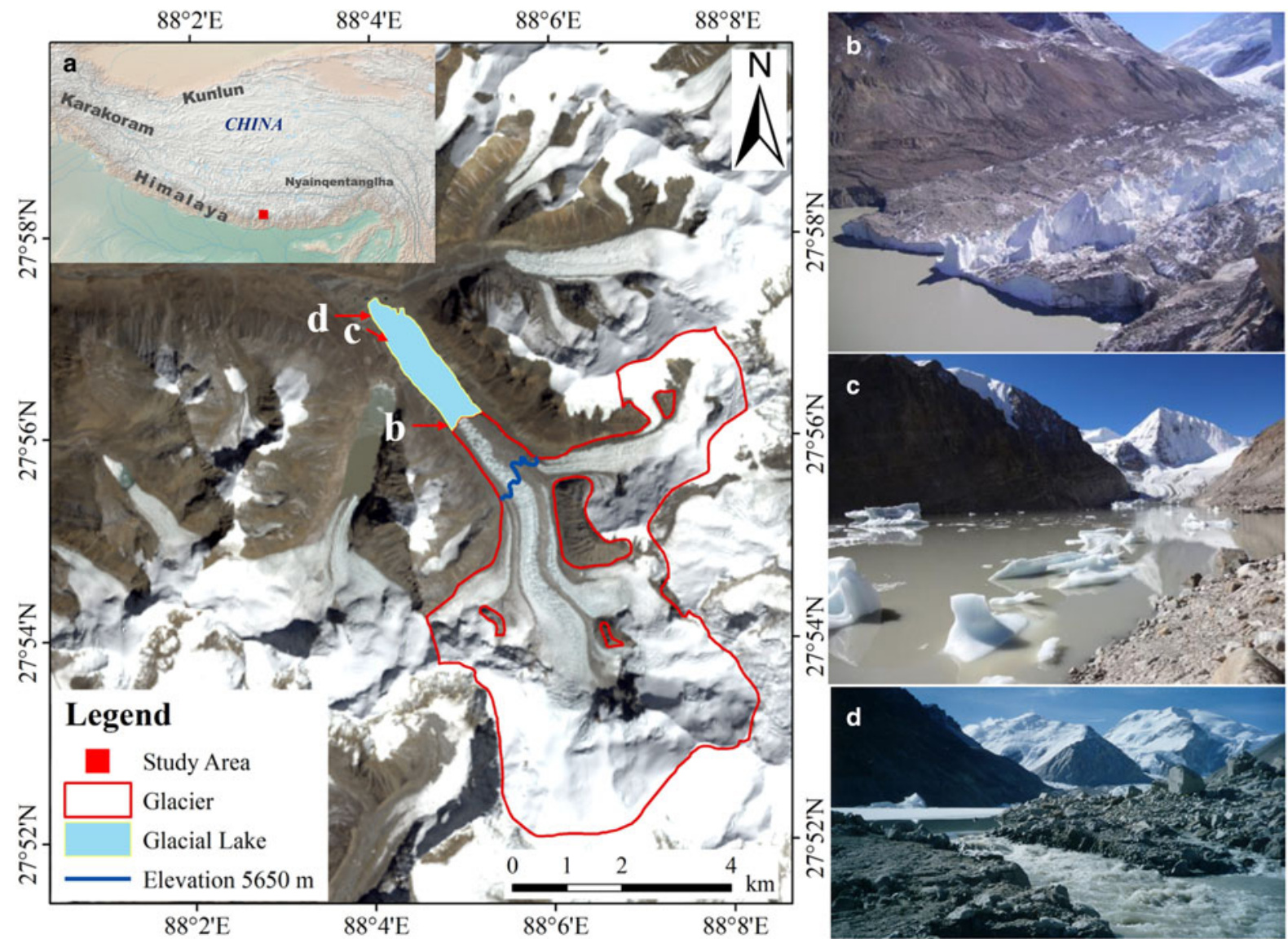

Fig. 1. (a) The study area. The outlines of Longbasaba Glacier/Lake were manually delineated from the Landsat OLI image taken on 17 October 2018 . The inset has a Natural Earth shaded relief background. The blue line, with an elevation of $5650 \mathrm{~m}$ obtained from the SRTM DEM, shows the intersection between the glacier main channel and the tributaries. The glacier tongue is defined as the area lower than the blue line. The red arrow shows the direction in which the sub-images (b, $c$, $d$ ) were taken. (b) Crevasses and debris cover on the glacier tongue. (c) Icebergs widely distributed over the lake surface. (d) The water outlet of Longbasaba Lake in June 2006.

terminus of its host glacier $\left(1264 \mathrm{~m}, 40 \mathrm{~m} \mathrm{a}^{-1}\right)$, the lake area has increased by $223 \%$ from $1977-2009$ (Wang and others, 2016), whereas the glacial lakes in the Himalaya have expanded by $14.1 \%$ on average during 1990-2015 (Nie and others, 2017). In addition, an accelerating retreat of the glacier terminus $\left(63.8 \mathrm{~m} \mathrm{a}^{-1}\right)$ was observed for Longbasaba Lake during 2005-09, resulting in a lake area expansion rate of $0.040 \mathrm{~km}^{2} \mathrm{a}^{-1}$ (Wang and others, 2016). The ice core in the moraine dam of this lake has been deteriorating during the last few decades, which is manifested as an increasing yearly maximum thawing depth and a decreasing yearly maximum freezing depth (Wang and others, 2018). These changes will decrease the moraine dam stability and may increase the risk of dam failure. A modeled outburst flood from Longbasaba Lake and the adjacent proglacial lake, Pida Lake, projects that the water flux would reach $3-5 \times 10^{4} \mathrm{~m}^{3} \mathrm{~s}^{-1}$ within $\sim 1.8 \mathrm{~h}$ after the beginning of the flood (Wang and others, 2008). The Hydrological Department of the Tibet Autonomous Region has suggested that a GLOF from Longbasaba Lake would damage the roads, bridges and the hydropower station downstream and would threaten the towns of Saer and Jiangge, along with 23 other villages (Yao and others, 2012b). Thus, the evolution of Longbasaba Glacier and Lake needs to be monitored and has attracted the attention of scientists and local government departments (Wang and others, 2008, 2018; Yao and others, 2012b; Nie and others, 2017). Here, we provide an approach to assess the mass budget from glacier recession by calculating the corresponding mass loss contributions from different components of glacier fluctuations. The goal of this study is to detect the variations in the glacier mass budget and the lake area, to estimate the expansion of the lake water volume, and then, to assess the mass impacts of the glacier degradation on the water volume of Longbasaba Lake.

\section{Study area}

Longbasaba Glacier has a proglacial moraine-dammed lake and is located in the headwaters of the Pumqu River on the northern slope of the central eastern Himalaya (Fig. 1a). This glacier covered an area of $28.4 \mathrm{~km}^{2}$ in 2010 , with a length of $8.7 \mathrm{~km}$ and a debris-covered area of $1.1 \mathrm{~km}^{2}$ on the tongue (3.7\%) (Guo and others, 2015). Many crevasses have formed on the glacier tongue (Fig. 1b) and are likely produced due to extending flow as a result of calving, which produces icebergs with various sizes in the lake (Fig. 1c). Longbasaba Lake remains at a high risk of outburst (Wang and others, 2016). It covered an area of $1.22 \mathrm{~km}^{2}$ in 2009 , with a maximum SE-NW length of $2.210 \mathrm{~km}$ and a maximum SW-NE width of $0.685 \mathrm{~km}$ (Yao and others, 2012b). According to in situ measurements conducted using an echo sounder with a GPS receiver in September 2009, the water level of Longbasaba Lake was at $5499 \mathrm{~m}$ a.s.l. and the average and maximum lake depths were 48 and $102 \mathrm{~m}$, respectively, contributing a water volume of $\sim 0.064 \mathrm{~km}^{3}$ (Yao and others, 2012b).

\section{Data and methods}

\section{Changes in glacier area, length and surface velocity}

Variations in glacier area and length were determined based on 34 Landsat TM $\backslash \mathrm{ETM}+\mid \mathrm{OLI}$ images acquired during 1988-2018 (Table S1). These multispectral, multitemporal images, with a 
spatial resolution of $30 \mathrm{~m}$ and the coordinate system of the WGS1984/EGM1996, are available from, and were orthorectified by, the United States Geological Survey (USGS). The Landsat images showed a horizontal accuracy of better than one pixel to each other or to non-differential GPS data (Bolch and others, 2010; Guo and others, 2013) and have been widely used in glaciology (Guo and others, 2015; Cogley, 2016; Azam and others, 2018; Nie and others, 2018; Wu and others, 2018; Begam and others, 2019; Liu and others, 2020).

Landsat images covering the study region were affected by frequent snow and cloud cover. We preferentially chose images acquired in September and October with minimum snow and cloud cover. Some high-quality images acquired in the adjacent months (e.g. July and August) were used when there was no suitable image in September and October (Fig. S1a). In addition, scanline errors (SLC-off scenes acquired by the ETM+ sensor since early summer 2003) also created obstacles in generating the glacier/lake outlines (Fig. S1b). Then, the SLC-off images were used only to identify the glacier front positions. The glacier outlines were manually mapped, and subsequently, the areal variation during the investigation period was generated. The center flowlines were also manually digitized to assess the changes in the glacier length.

Glacier surface velocities were extracted from Landsat image pairs utilizing the cross-correlation feature tracking processing in a free software module Co-registration of Optically Sensed Images and Correlation (COSI-Corr) (Leprince and others, 2007; Gantayat and others, 2014; Ruiz and others, 2015; Ayoub and others, 2017). A co-registered image pair containing two Landsat images was iteratively cross-correlated in a sliding window with 32 pixels and a step size of one pixel. Then, two horizontal ground offset fields (East $\backslash$ West and North $\backslash$ South) with a spatial resolution of $30 \mathrm{~m}$ were calculated for each pixel. The signal-to-noise ratio (SNR) was calculated using the frequency mask and the weighting matrix, and it reflects the quality of the correlation (Leprince and others, 2007). The surface velocity of an individual pixel was generated by combining two horizontal offsets with an SNR threshold of $>0.95$. The mean surface velocity of the glacier (MSVg) was extracted over the glacier terrain using a 95\% quantile boundary to eliminate the extreme outliers. In addition, the mean surface velocity of the glacier tongue (MSVt) was generated using the same threshold of pixels over the glacier tongue region. Unfortunately, there was no perfect Landsat image covering the entire glacier in 2012, so the surface velocities over the periods 2011-12 and 2012-13 were replaced by the mean surface velocity extracted from the Landsat images in 2011 and 2013.

The changes in the surface elevation were obtained from the High Mountain Asia Gridded Glacier Thickness Changes from Multi-Sensor DEMs, Version 1 (HMA_Glacier_dH) for two subsequent time periods of 1975-2000 and 2000-16 (Maurer and others, 2018). These data were extracted based on a series of stereo scenes from KH-9 HEXAGON in 1975 and ASTER data acquired from 2000 to 2016 by fitting robust linear trends. These data are available from the National Snow and Ice Data Center (NSIDC) and have a horizontal resolution of $30 \mathrm{~m}$. The asserted accuracy of the full dataset is $\pm 0.42 \mathrm{~m} \mathrm{a}^{-1}$ as derived from the non-glacier terrain and varies between the glaciers and sub-regions due to the different data quality and coverage (Maurer and others, 2018). In this study, we obtained a higher accuracy of $\pm 0.04 \mathrm{~m} \mathrm{a}^{-1}$ for the two periods 1975-2000 and 2000-16, using the method of Brun and others (2017).

\section{Changes in glacial lake area and water volume}

The changes in the lake area were obtained from the Landsat images used to generate the glacier outlines in order to ensure that there was no gap between the glacier/lake outlines. The water volume was estimated by multiplying the lake area and depth. In situ measurements of the water depths of Longbasaba Lake were taken in September 2009, using a comprehensive measuring system containing an echo sounder and a GPS receiver (Yao and others, 2012b). A total of 35558 depth points with positions were collected (Fig. S2a). Another 33 random points were obtained synchronously using a measuring rope. The depth error was $\pm 2.0 \mathrm{~m}$ by comparing the depth measured by the echo sounder and that obtained using the measuring rope. Considering the vertical errors controlled by the rope drift and GPS horizontal errors, the in situ measurements showed a depth accuracy of $\pm 2.5 \mathrm{~m}$ (see Fig. S3 and Table S2). Combining the water depth measurements and the lake boundary in 2009, the isobaths with $10 \mathrm{~m}$ intervals for the lake basin were extracted using the ordinary kriging interpolation method with a search radius of 12 pixels and a spherical semivariogram model. Subsequently, the basin morphology within the 2009 lake boundary was reconstructed using a water level of $5499 \mathrm{~m}$ a.s.l. Based on this morphology (Fig. S2b), the lowest elevation of the lake basin was $5398 \mathrm{~m}$ a.s.l. in 2009 .

By comparing the ice thickness and surface DEM of mountain glaciers provided by Farinotti and others (2019), we generated the bed topography with $10 \mathrm{~m}$ intervals for Longbasaba Glacier (Fig. S2d). These ice thickness data are a consensus estimate based on five ice thickness estimation models (Farinotti and others, 2019). The original consensus ice thickness suggested a gentle gradient at the glacier's terminus, which was inconsistent with the steep cliff at the front of the host glacier (Fig. 1b). Thus, the isobaths just within the 2014 glacier boundary were used and merged with the 2009 lake isobaths by taking into account the basin's continuity (Fig. S2e). Based on the merged isobaths and the 2018 glacial lake boundary, the 'hole' in the basin morphology between the 2009 and 2014 glacier terminus locations was estimated using the 'topo to raster' module in ArcGIS 10.2, which is based on the ANUDEM method (Hutchinson, 2004). Finally, the 2018 basin morphology for the proglacial lake, with a spatial resolution of $30 \mathrm{~m}$, was reconstructed (Fig. S2f). The lake water volume in each year, $V_{1}$, was estimated using:

$$
\mathrm{V}_{\mathrm{l}}=\frac{S}{N_{\mathrm{l}}} \sum_{i=1}^{N_{\mathrm{l}}} h_{\mathrm{l}}^{i}
$$

where $N_{1}$ is the pixel number within the lake boundary in each year; $h_{1}^{i}$ is the depth of the individual pixel, which can be calculated by comparing the water level and the basin morphology; and $S$ is the lake area in the corresponding year.

In High Mountain Asia, the rate of the rise in lake water level was $0.14-0.18 \mathrm{~m} \mathrm{a}^{-1}$ on average between 1990 and 2015 (Treichler and others, 2019) and increased to $0.21 \mathrm{~m} \mathrm{a}^{-1}$ during 2003-09 (Zhang and others, 2017). Furthermore, the lake water level in the southwestern part of the Tibetan Plateau has risen by $4 \pm 1 \mathrm{~mm} \mathrm{a}^{-1}$ on average during 1990-2015 (Treichler and others, 2019). Following the rate from Treichler and others (2019), the maximum mean rate of increase of the Longbasaba Lake water level, with a mean lake depth of $\sim 50 \mathrm{~m}$, would be $0.2 \mathrm{~m} \mathrm{a}^{-1}$. This results in an underestimation of $<1.2 \%$ relative to the estimated water volume using our measurement. Thus, we assumed in this study that the lake experienced a negligible interannual change in water level during the investigation period.

\section{Mass contributions of glacier wastage to lake water volume}

Due to the effects of climate warming and the formation of proglacial lakes, the mass wastage of lake-terminating glaciers is 


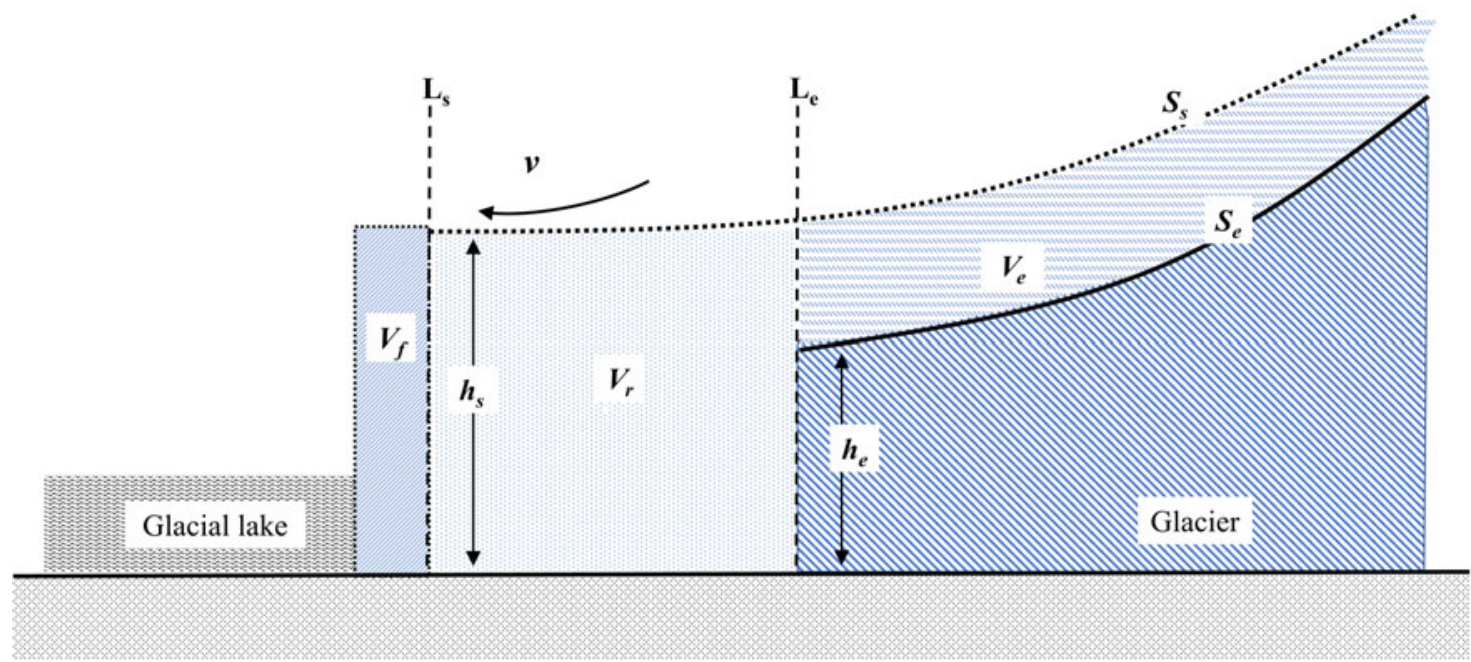

Fig. 2. Mass fluctuation components of a lake-terminating glacier and its contribution to lake water volume. $L_{s}, S_{\mathrm{s}}$ and $h_{\mathrm{s}}$ are the glacier front, glacier surface and ice thickness in a specific year; $L_{\mathrm{e}}, S_{\mathrm{e}}$ and $h_{\mathrm{e}}$ are the glacier front, glacier surface and ice thickness after retreat in the next year; $v$ is the surface ice flow velocity; $V_{\mathrm{e}}$ is the ice volume loss contributed by the glacier surface lowering; and $V_{\mathrm{f}}$ and $V_{\mathrm{r}}$ are the ice losses contributed by the ice flow and the terminus retreat, respectively.

characterized by terminus retreat and surface lowering (Fig. 2). At the glacier terminus, the mass loss from ice melt and calving directly enters the proglacial lake. Meltwater from glacier ablation is manifested as three components: water inflow directly into the proglacial lake, evaporation (or sublimation directly from ice) into the air and infiltration into the ground. For lake-terminating glaciers, mass balance that is assessed by geodetic measurements solely based on glacier surface lowering underestimates mass contributions, as movement from the glacier terminus is not considered. Without the consideration of the negligible amounts of evaporation and percolation (Brock and others, 2010; Zhang and others, 2012; Lei and others, 2013; Treichler and others, 2019), the mass impacts of the glacier change on the lake water volume can be divided into two portions: the mass contribution from the terminus dynamics, $M_{\mathrm{t}}$; and the mass contribution that is not from the terminus dynamics (mainly from glacier surface lowering), $M_{\mathrm{s}}$. The former can be further divided into two phases: (i) terminus advance and subsequent ice melt and calving from the advanced ice according to the ice flow, $M_{\mathrm{f}}$, and (ii) synchronous terminus retreat without considering the ice flow, $M_{\mathrm{r}}$, only due to ice melt and calving at the glacier terminus. Then, the impact of the glacier wastage on the lake water volume can be classified into three synchronous components of ice loss contributed by: (i) ice flow, $V_{\text {f }}$ (ii) terminus retreat, $V_{\mathrm{r}}$; and (iii) glacier surface lowering over the area higher than $L_{\mathrm{e}}, V_{\mathrm{e}}$ (Fig. 2). Eventually, the mass contributions of the glacier changes to the lake water volume, $M_{\mathrm{G}}$, can be calculated as:

$$
M_{\mathrm{G}}=M_{\mathrm{f}}+M_{\mathrm{r}}+M_{\mathrm{s}}=V_{\mathrm{f}} \rho_{\text {ice }}+V_{\mathrm{r}} \rho_{\text {ice }}+V_{\mathrm{e}} \rho_{\text {gla }},
$$

where $\rho_{\text {ice }}$ is the ice density of the glacier tongue, with a constant value of $900 \mathrm{~kg} \mathrm{~m}^{-3}$ as recommended by Kääb and others (2012); $\rho_{\text {gla }}$ is the consensus glacier density for the long-timescale estimation, with a value of $850 \pm 60 \mathrm{~kg} \mathrm{~m}^{-3}$ suggested by Huss (2013).

The ice volume contributed by the ice flow of the glacier terminus can be estimated as:

$$
V_{\mathrm{f}}=\frac{v t}{R} \sum_{i=1}^{N_{\mathrm{f}}} h_{\mathrm{s}}^{i} s_{i},
$$

where $v$ is the ice flow velocity at the glacier terminus; $t$ is the interval time; $R$ is the spatial resolution of the pixel; $N_{\mathrm{f}}$ is the number of pixels within the profile of the glacier front; $h_{\mathrm{s}}^{i}$ is the ice thickness for an individual pixel in the previous year; and $s_{i}$ is the pixel area.

The ice flow velocities of glaciers depend on factors such as the bed gradient, glacier thickness, the mass balance, ice temperature and subglacial hydrology (Paterson, 1994; Dehecq and others, 2018). The annual mean air temperature of $-3.6^{\circ} \mathrm{C}$ in our study area (Wang and others, 2018) was suggested to be $2-4^{\circ} \mathrm{C}$ colder than ice temperatures of glaciers (Liu and others, 2009; Miles and others, 2018). It indicates that Longbasaba Glacier is a temperature glacier, and its basal velocities should be generally characterized by a more uniform distribution across the ice body (Paterson, 1994). In previous studies, the basal velocity was suggested to account $30-80 \%$ of the surface velocity (Perutz, 1949; Harper and others, 2001; Copland and others, 2003). For Koxkar Glacier in the Tien Shan, the basal sliding contributed 33\% of the surface velocity ( $\mathrm{Li}$ and others, 2014). Therefore, we assumed that the basal velocity accounted for $40 \%$ of the surface velocity at the glacier terminus for Longbasaba Glacier, and the value of $70 \%$ of the MSVt was obtained as the value of the ice flow velocity for the glacier terminus, by averaging the basal (40\%) and surface (100\%) velocities. The minimum and maximum values (30 and $80 \%)$ of the potential basal velocity range were also tested and led to variations of $<1 \%$ for the results in this study.

The ice thickness of the glacier terminus was calculated by comparing the surface/bed elevations at the glacier front in a specific year. The surface elevation of Longbasaba Glacier in 1980 was extracted from the 1:50 000 Chinese historical topographic map (Wei and others, 2015; Wu and others, 2018). By combining the position and bed elevation of the glacier front, the ice thicknesses of the glacier terminus from 1988 to 2018 were generated and modified using the average surface-lowering rates of the glacier tongue. Based on the HMA_Glacier_dH data (Maurer and others, 2018), the mean thinning rate of glacier tongue was $\sim-0.89 \pm 0.04 \mathrm{~m} \mathrm{a}^{-1}$ during $1975-2000$, and it increased to $-2.04 \pm 0.04 \mathrm{~m} \mathrm{a}^{-1}$ during 2000-16.

The ice volume loss contributed by the retreat of the glacier front was:

$$
V_{\mathrm{r}}=\sum_{i=1}^{N_{\mathrm{r}}} h_{\mathrm{s}}^{i} s_{i},
$$

where $N_{\mathrm{r}}$ is the number of pixels over the terrain between the profiles of $L_{\mathrm{s}}$ and $L_{\mathrm{e}}$ (Fig. 2). The changes in the ice volume 


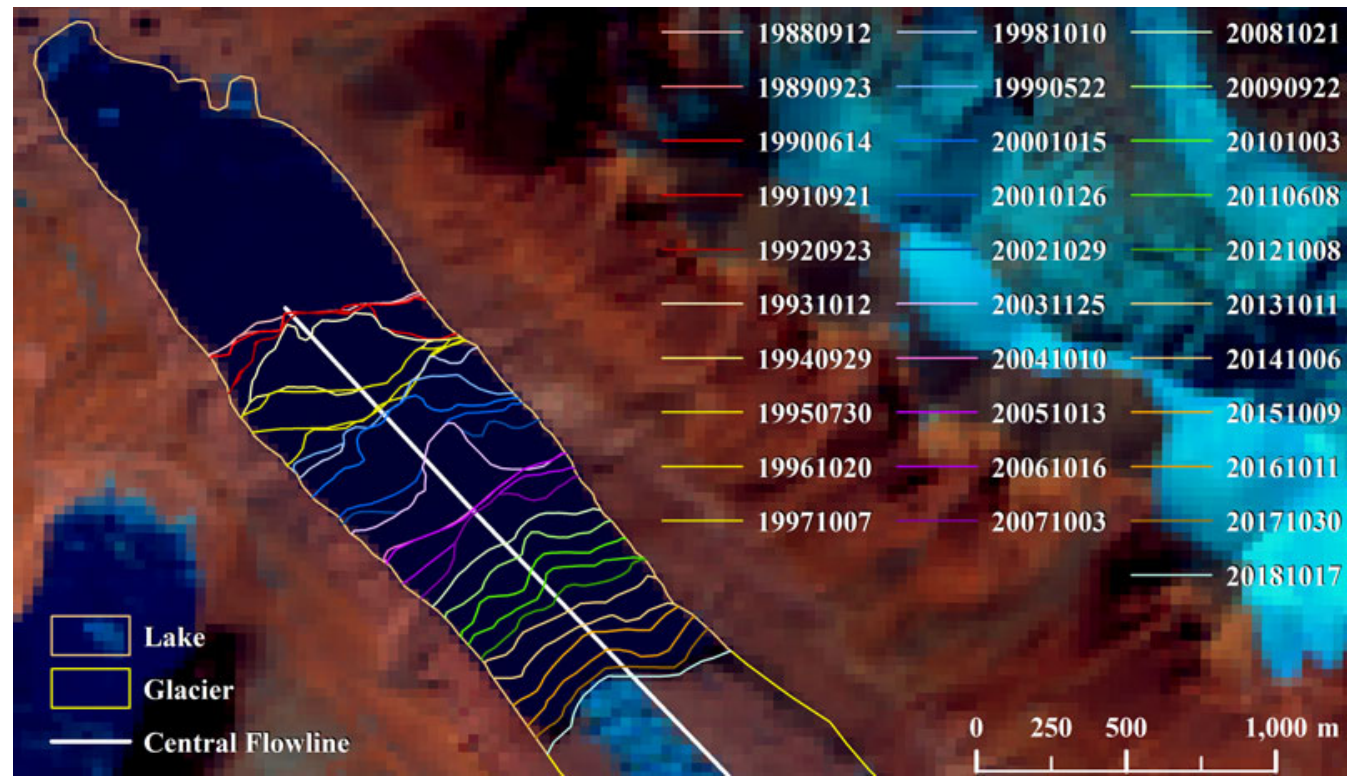

Fig. 3. Variation in the front positions of Longbasaba Glacier, generated from Landsat images taken during 1988-2018. The background map is the Landsat OLI image taken on 17 October 2018. The white line is the center flowline.

contributed by the surface lowering, $V_{\mathrm{e}}$, can be estimated as:

$$
V_{\mathrm{e}}=\overline{h_{\Delta}} s_{\mathrm{g}}
$$

where $s_{\mathrm{g}}$ and $\overline{h_{\Delta}}$ are the glacier area and average thinning rate higher than $L_{\mathrm{e}}$, respectively. The mean changes in glacier surface elevation during the two periods $1975-2000$ and 2000-16 were extracted from the HMA_Glacier_dH data.

\section{Background of climate change}

The background of climate change in the study area was analyzed based on the China Meteorological Forcing Dataset (CMFD) released by the National Tibetan Plateau Data Center ( $\mathrm{He}$ and others, 2020). Using a combination of in situ station data, gridded datasets from remote-sensing products, and reanalysis datasets, the CMFD data product releases the instantaneous surface $(2 \mathrm{~m})$ air temperature and $3 \mathrm{~h}$ mean precipitation rate required for land modeling during 1979-2018. These data are available as tiles with a temporal resolution of $3 \mathrm{~h}$ and a spatial resolution of $0.1^{\circ}$, and distributed on daily, monthly and yearly scales (Yang and $\mathrm{He}, 2018$ ). Here, we generated the changes in the yearly mean air temperature and precipitation during the past three decades, to discuss their effect on the changes of Longbasaba Glacier.

\section{Accuracy analysis}

The geolocation errors of the pixels on the glacier/lake boundaries, generated through a careful manual approach, can be controlled within a pixel. By comparing the outline positions from the manual delineation and GPS measurements, Guo and others (2015) suggested that the accuracies of manual outlines were $\sim \pm 11$ and $\pm 30 \mathrm{~m}$ for clean ice and debris-covered glaciers, respectively. In this study, the position accuracy of glacier boundary was affected by the debris cover on the glacier tongue but without the glacier terminus, as it was easy to exactly distinguish the glacier from its proglacial lake. The accuracies of the generated area are defined by the buffer along the glacier/lake perimeters with the size of half of the outline position error, and equal to 0.5 pixels multiplied by the pixel number within the perimeters and the spatial resolution of the images (Bolch and others, 2010; Guo and others, 2015). The maximum error for the glacier area was $\pm 0.665 \mathrm{~km}^{2}$ in 1988 , and for the lake area the value was $\pm 0.104 \mathrm{~km}^{2}$ in 2018 , with mean accuracies of $\pm 0.644 \mathrm{~km}^{2}(2 \%)$ and $\pm 0.078 \mathrm{~km}^{2}(7 \%)$ for glacier and lake areas, respectively. The accuracy of the central flowline length was also controlled within 0.5 pixels, approximately equal to $\pm 15 \mathrm{~m}$, which caused an accuracy of $\pm 21 \mathrm{~m}$ for the changes in the glacier length according to the law of error propagation. For the accumulation area of Longbasaba Glacier, the changes of a few pixels suggested a 'stable' outline during the investigation period. The accuracy of changes in the glacier/lake areas was predominantly controlled by the perimeters of the digital polygons defining the area changes, and it ranged from \pm 0.017 to $\pm 0.027 \mathrm{~km}^{2}$ during each interval, using the buffer method (Bolch and others, 2010; Guo and others, 2015).

The accuracy of the estimated water volume was assessed according to the law of error propagation, based on errors of the lake depth and area. The error of interpolation method was estimated from the differences of depth values of the 35558 points between the in situ measurements and the 2018 basin morphology. Based on the mean and square deviation (SD) values of 0.2 and $4.9 \mathrm{~m}$, respectively, the interpolated result showed an accuracy of $\pm 4.9 \mathrm{~m}$ by following $\sqrt{(\mathrm{mean})^{2}+(\mathrm{SD})^{2}}$ (Wei and others, 2015). Considering the accuracy of $\pm 2.5 \mathrm{~m}$ for the lake depth obtained from the in situ measurements, the estimated accuracy of the lake basin depth was $\pm \sqrt{(2.5)^{2}+(4.9)^{2}}= \pm 5.5 \mathrm{~m}$.

The uncertainties of the mass contributions from the glacier terminus motions and surface lowering were mainly controlled by the errors in the glacier surface velocity, ice thickness and thinning rate. The error of the surface velocity was obtained from the stable glacier-free terrain in the investigated region, and ranged from \pm 0.23 to $\pm 2.36 \mathrm{~cm} \mathrm{~d}^{-1}$. The accuracy in the glacier thinning rate depends on the precision of the HMA_Glacier_dH data and approximately equaled to $\pm 0.04 \mathrm{~m} \mathrm{a}^{-1}$ for the two periods 1975-2000 and 2000-16. The uncertainty in the ice thickness was determined from the errors in the elevations of the glacier surface and bed at the glacier tongue. The precision of the glacier surface elevations was controlled by the accuracies of the topographic maps and the elevation-lowering rates of the glacier tongue. The topographic maps showed a vertical accuracy of $\pm 8 \mathrm{~m}$ for 


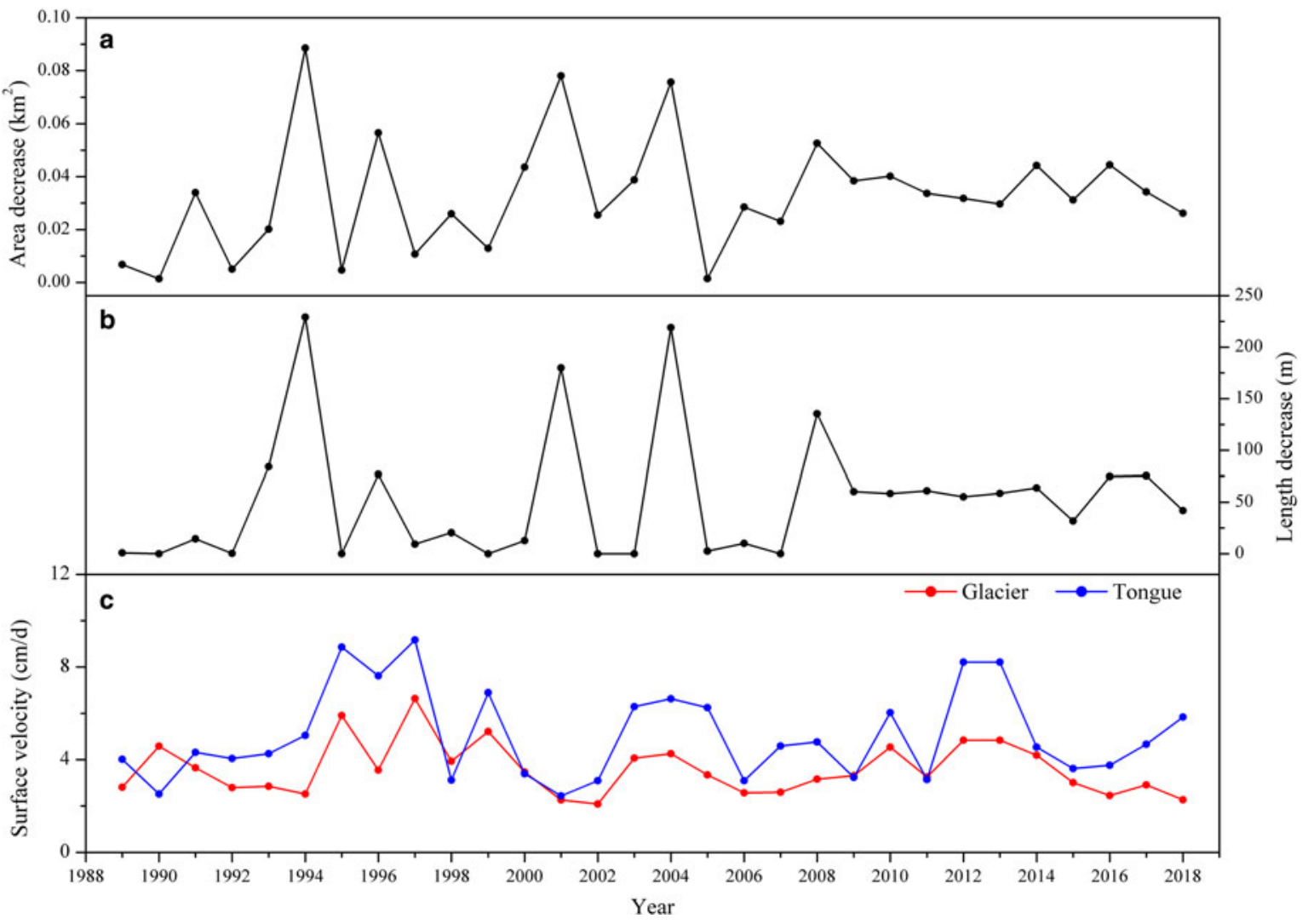

Fig. 4. Changes in (a) area, (b) length and (c) mean surface velocity for Longbasaba Glacier during 1989-2018. The recessions of glacier area and length were more variable prior to 2008 than in the last decade. The glacier length changes were determined by comparing the positions of the intersection points between the center flowline and the glacier fronts.

areas with slopes of $6-25^{\circ}$ (Chinese National Standard, 2008). The error in the lake depth was used to assess the accuracy of the bed elevations. Then the estimated accuracy of the ice thickness equaled to $\pm 9.6 \mathrm{~m}$, and finally caused an accuracy of $\pm 0.018 \mathrm{~km}^{3}$ for the total mass loss from the glacier recession during the period $1988-2018$.

\section{Results}

\section{Glacier recession}

The total area of Longbasaba Glacier was $29.551 \pm 0.617 \mathrm{~km}^{2}$ in 2018 and decreased by $3.23 \%$ since 1988 (Fig. 3), with a mean areal recession rate of $0.033 \pm 0.001 \mathrm{~km}^{2} \mathrm{a}^{-1}$. The glacier recession varied dramatically with an SD value of $0.027 \mathrm{~km}^{2}$ during $1988-$ 2008 , whereas with less variation $\left(\mathrm{SD}\right.$ of $\left.0.006 \mathrm{~km}^{2}\right)$ in the recent decade (Fig. 4a). The greatest area loss occurred from 1993 to 1994 , causing an area of $0.089 \pm 0.026 \mathrm{~km}^{2}(0.29 \%)$ to disappear. During 2000-01 and 2003-04, this glacier experienced a significant amount of recession, with a degradation area of $>0.075 \mathrm{~km}^{2}$. However, the glacier area decreased by $<0.05 \mathrm{~km}^{2}$ during the other periods before 2008. In particular, during the periods of 1988-89, 1989-90, 1991-92, 1994-95 and 2004-05, this glacier remained nearly stable, with an area loss of $<0.01 \mathrm{~km}^{2}$. The glacier retreated slower prior to 2008 (mean $0.032 \pm 0.003 \mathrm{~km}^{2} \mathrm{a}^{-1}$ ) than in the last decade $\left(0.035 \pm 0.001 \mathrm{~km}^{2} \mathrm{a}^{-1}\right)$.

The length of the center flowline was $8274 \pm 15 \mathrm{~m}$ in 2018 , and it has decreased by $1577 \pm 21 \mathrm{~m}\left(53 \pm 1 \mathrm{~m} \mathrm{a}^{-1}\right)$ from 1988 to 2018 (Fig. 4b). A higher mean length retreat $\left(58 \pm 2 \mathrm{~m} \mathrm{a}^{-1}\right)$ occurred during 2008-18 than in 1988-2008 $\left(50 \pm 1 \mathrm{~m} \mathrm{a}^{-1}\right)$. The variation in the glacier length was dramatic before 2008, with an SD value of $78 \mathrm{~m}$ relative to the value of $13 \mathrm{~m}$ during 2008-18. The largest reductions in length occurred during
1993-94, 2000-01 and 2003-04, with retreat rates of $>180 \mathrm{~m}$ $\mathrm{a}^{-1}$. Nevertheless, the length of the center flowline changed slightly within a pixel or remained nearly stable during the other periods before 2008 .

The MSVg was $3.60 \pm 1.03 \mathrm{~cm} \mathrm{~d}^{-1}$ during the investigation period, ranging from $2.08 \pm 0.41 \mathrm{~cm} \mathrm{~d}^{-1}$ during 2001-02 to $6.64 \pm$ $1.78 \mathrm{~cm} \mathrm{~d}^{-1}$ during 1996-97. The MSVt was $5.05 \pm 1.03 \mathrm{~cm} \mathrm{~d}^{-1}$ during 1988-2018, which is $65 \%$ faster than the MSVg. The decreases in the MSVg were observed during the periods 1988 -2008 and 2008-18, and the decrease rate has increased during the last decade (Fig. 4c). An approximately synchronous fluctuation was observed for the MSVg and MSVt, while the variation in the magnitude of the MSVt was greater than that of the MSVg, with SD values of 1.89 and $1.12 \mathrm{~cm} \mathrm{~d}^{-1}$ for MSVt and MSVg, respectively. The change in the MSVg is not consistent with the changes in the glacier area and length, with correlation coefficients of $<0.3$.

According to the consensus estimate of the ice thickness from Farinotti and others (2019), the total ice volume of Longbasaba Glacier was $\sim 3.317 \mathrm{~km}^{3}$ (Fig. 5). The mean surface-lowering rate was $-0.38 \pm 0.04 \mathrm{~m} \mathrm{a}^{-1}$ from 1975 to 2000 based on the HMA_Glacier_dH data, resulting in a total ice loss of $0.139 \pm$ $0.001 \mathrm{~km}^{3}$ (4.2\% of the total ice volume) from 1988 to 2000 . The thinning rate decreased slightly to an average of $-0.28 \pm$ $0.04 \mathrm{~m} \mathrm{a}^{-1}$ from 2000 to 2016, resulting in an ice loss of 0.100 $\pm 0.001 \mathrm{~km}^{3}$ (3.0\% of the total ice volume) during 2000-18. In contrast, the glacier tongue experienced a greater and accelerating shrinkage, with mean thinning rates from $-0.89 \pm 0.04 \mathrm{~m} \mathrm{a}^{-1}$ before 2000 to $-2.04 \pm 0.04 \mathrm{~m} \mathrm{a}^{-1}$ after 2000 . Finally, an average surface lowering of $-0.34 \pm 0.04 \mathrm{~m} \mathrm{a}^{-1}$ occurred from 1975 to 2016 , contributing an average mass wastage of $-0.27 \pm 0.04 \mathrm{~m}$ w.e. $\mathrm{a}^{-1}$ during 1988-2018. 

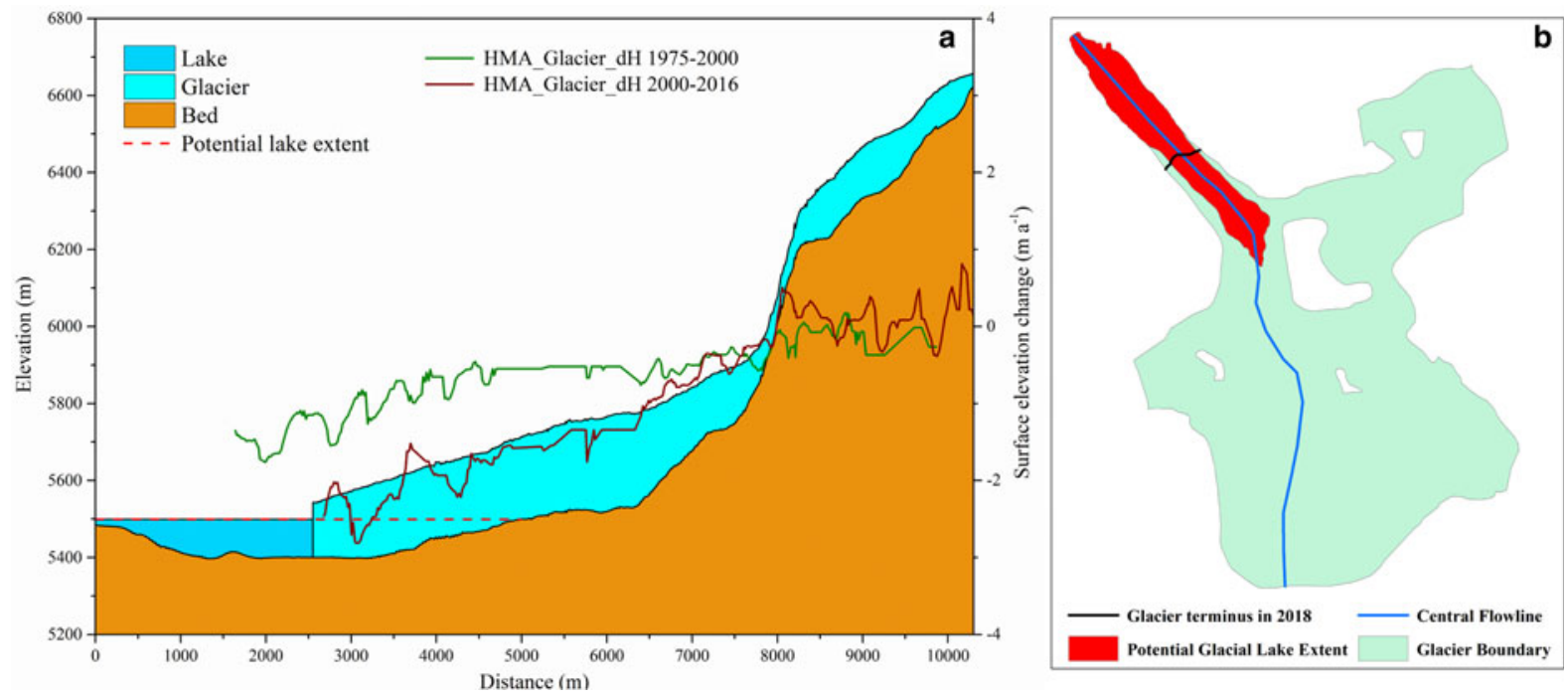

Fig. 5. (a) The center flowline profiles of the bed, ice thickness, lake depth and surface lowering rates of Longbasaba Glacier. The basin morphology of Longbasaba Lake and the bed/ice-thickness of Longbasaba Glacier were reconstructed from the echo sounder measurements of Yao and others (2012b), and the ice thickness and surface DEM of Farinotti and others (2019). The surface-lowering rates are from the HMA_Glacier_dH dataset during periods 1975-2000 and 2000-16 (Maurer and others, 2018). (b) The potential maximum lake extent when the glacier terminus is separated from the lake in the future, by assuming no change in lake water level.

\section{Glacial lake expansion}

Accompanied by the degradation of the host glacier, the area of Longbasaba Lake has expanded by $164 \%\left(3.3 \% \mathrm{a}^{-1}\right)$ to $1.591 \pm 0.104 \mathrm{~km}^{2}$ in 2018 (Fig. 6a), with an increased mean rate of expansion of $0.033 \pm 0.001 \mathrm{~km}^{2} \mathrm{a}^{-1}$ over the past three decades. Similar to its host glacier, the lake expanded with more variable rates before 2008 than during the last decade (Fig. 4a).

Based on the estimated basin morphology (Fig. 5a), the maximum lake depth was $102.3 \pm 5.5 \mathrm{~m}$ in 2018. Over the period of $1988-2018$, the water volume increased by $237 \%$ to $0.083 \pm$ $0.025 \mathrm{~km}^{3}$ in 2018 (Fig. 6b). The mean increase in water volume was $0.002 \pm 0.001 \mathrm{~km}^{3} \mathrm{a}^{-1}$ during $1988-2008$, with a lower rate during the past decade $\left(0.001 \pm 0.001 \mathrm{~km}^{3} \mathrm{a}^{-1}\right)$. The most dramatic water volume increases $\left(>0.05 \mathrm{~km}^{3}\right)$ occurred during 1993-94, 2000-01 and 2003-04, when synchronous dramatic decreases in glacier area and length were observed (Fig. 6b).

\section{Glacier mass loss}

Over the last three decades, a total mass loss of $0.286 \pm 0.018 \mathrm{~km}^{3}$ w.e. from the host glacier was released into the proglacial lake (Table 1). The mean mass loss of Longbasaba Glacier decreased from an average of $0.012 \pm 0.001 \mathrm{~km}^{3}$ w.e. $\mathrm{a}^{-1}$ during 1988 2000 to $0.010 \pm 0.001 \mathrm{~km}^{3}$ w.e $\mathrm{a}^{-1}$ during $2000-18$. The mean water inflow contributed by the glacier recession was $36 \%$ of the mean lake volume from 1988 to 2000 , and the percentage was three times greater than the value (11\%) during 2000-18. These mass budgets result in mean mass balances of $-0.40 \pm$ $0.02 \mathrm{~m}$ w.e. $\mathrm{a}^{-1}$ during $1988-2000$ and $-0.26 \pm 0.02 \mathrm{~m}$ w.e. $\mathrm{a}^{-1}$ during 2000-18, contributing water to the lake at a mean mass balance magnitude of $-0.32 \pm 0.02 \mathrm{~m}$ w.e. $\mathrm{a}^{-1}$ over the last three decades.

The water inflow released by the glacier degradation was predominately due to the glacier surface lowering, which contributed $71 \%$ of the total glacier mass wastage during 1988-2018 (0.203 \pm $0.002 \mathrm{~km}^{3}$ w.e.). The remaining $23 \%$ of the mass budget was from glacier terminus retreat, with a water contribution of $0.066 \pm$ $0.008 \mathrm{~km}^{3}$ w.e. during $1988-2018$, while ice flow contributed $<7 \%$ of the mass budget. During 1988-2000 and 2000-18, the mass loss due to glacier surface lowering decreased by $28 \%$, accompanied by a lower mass contribution percentage over the last decade. At the same time, the mass contribution from the glacier terminus retreat doubled between the two periods, accompanied by the amplified contribution percentages from 5 to $7 \%$ in the ice flow. This caused the total mass loss contributed by the glacier terminus dynamics nearly to double between the two periods $1988-2000$ and $2000-18$.

\section{Discussion}

\section{Uncertainties in the estimated mass contributions from glacier recession to lake water volume}

For glaciers in high mountain regions, the groundwater system and evaporation/sublimation from glaciers have insignificant impacts on glacier hydrology and water resources in comparison to contributions from glacier melt and calving (Kang and others, 1999; Brock and others, 2010; Liu and others, 2010; Zhang and others, 2012). In addition, the evaporation loss from the glacier basin could be negligible for both current and warmer climate scenarios (Singha and others, 2005), due to the small vapor pressure gradient (Bengtsson, 1980). Lei and others (2013) and Treichler and others (2019) have both suggested that the groundwater exchange between different basins has a very limited influence on the water balance of the individual lakes according to the impermeability of the surrounding permafrost terrain. Thus, the overestimation of the mass contribution to lake water volume from glacier recession caused by ignoring the impact of evaporation/sublimation and infiltration is small and was considered to be negligible in this study. However, thawing of permafrost can become another potential source of water entering the proglacial lake.

\section{Mechanism of the changes of Longbasaba Glacier}

Glaciers in the Himalaya have experienced the greatest decrease in length and area, accompanied by the most negative mass balance in High Mountain Asia during the last decades (Yao and others, 2012a). However, heterogeneous glacier changes have been reported in previous studies (Kääb and others, 2012; Gardelle 


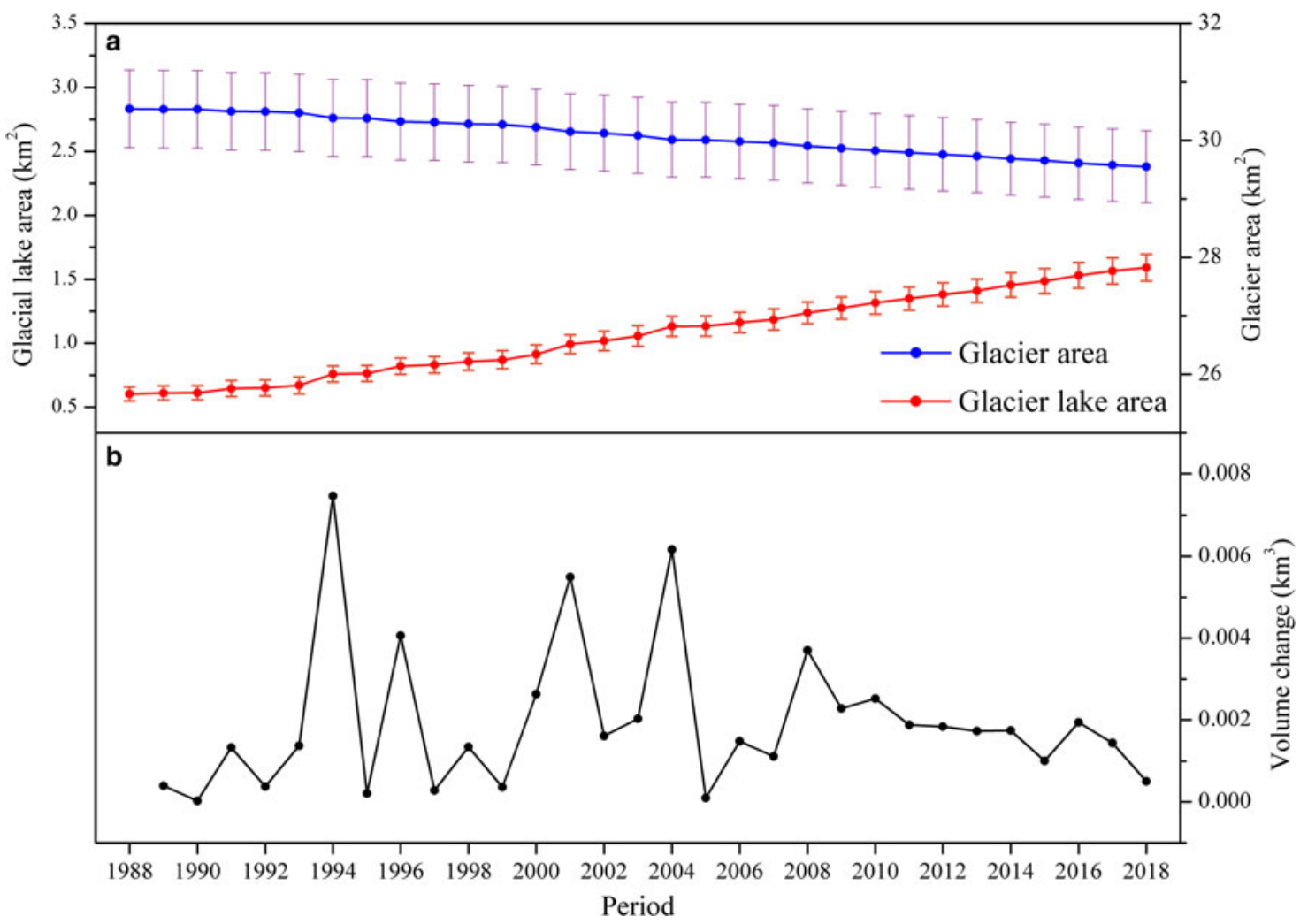

Fig. 6. (a) Time series of glacier and lake area and their errors during 1988-2018. (b) Changes in the water volume of Longbasaba Lake during $1988-2018$.

Table 1. Mass loss from Longbasaba Glacier during 1988-2018.

\begin{tabular}{lcrr}
\hline Period & $M_{\mathrm{f}}\left(p^{\star}\right)\left(\mathrm{km}^{3}\right)$ & $M_{\mathrm{r}}(p)\left(\mathrm{km}^{3}\right)$ & $M_{\mathrm{s}}(p)\left(\mathrm{km}^{3}\right)$ \\
\hline $1988-2000$ & $0.008 \pm 0.004(5 \%)$ & $0.021 \pm 0.003(14 \%)$ & $0.118 \pm 0.001(81 \%)$ \\
$2000-2018$ & $0.010 \pm 0.004(7 \%)$ & $0.046 \pm 0.005(33 \%)$ & $0.085 \pm 0.001(61 \%)$ \\
Total & $0.017 \pm 0.007(6 \%)$ & $0.066 \pm 0.008(23 \%)$ & $0.146 \pm 0.010$ \\
\hline
\end{tabular}

$p^{\star}$ : the mass contribution percentage relative to the total mass loss due to glacier recession.

The mass losses due to ice flow $\left(M_{\mathrm{f}}\right)$ and terminus retreat $\left(M_{\mathrm{r}}\right)$ are the total values over the corresponding periods. The mass losses due to surface lowering $\left(M_{\mathrm{s}}\right)$ were generated by multiplying the mean surface lowering and the mean glacier area of the corresponding periods.

and others, 2013; Cogley, 2016; King and others, 2017; Azam and others, 2018).

For the lake-terminating glaciers in the central eastern Himalaya, the mean mass balance was $-0.37 \pm 0.10 \mathrm{~m}$ w.e. $\mathrm{a}^{-1}$ before 2000 and increased to $-0.48 \pm 0.11 \mathrm{~m}$ w.e. $\mathrm{a}^{-1}$ from 2000 to 2015 (King and others, 2019). In contrast, Longbasaba Glacier has experienced a less negative mass loss contributed by the surface lowering, and the thinning rate of Longbasaba Glacier decreased from $1975-2000$ to $2000-16$, leading to significantly different mass loss mechanisms from the lake-terminating glaciers in the central eastern Himalaya during the last decade.

For Longbasaba Glacier, the mean air temperature has increased by $0.029 \pm 0.007^{\circ} \mathrm{Ca}^{-1}$ over the period of $1979-2018$, with a significant correlation at the 0.01 level (Fig. 7a). This warming rate was slightly greater than the temperature increase rate (mean $0.024 \pm 0.004^{\circ} \mathrm{Ca}^{-1}$ from 1967 to 2017) observed at Nyalam Station located at $3810 \mathrm{~m}$ a.s.l. and $210 \mathrm{~km}$ away from Longbasaba Glacier in the central Himalaya (Zhang and others, 2019). The changes in precipitation were heterogeneous in the central Himalaya (IPCC, 2018). An increase in precipitation was observed at Longbasaba Glacier, with a mean rate of $1.36 \pm 1.24$ $\mathrm{mm} \mathrm{a}^{-1}$ (Fig. $7 \mathrm{~b}$ ). In contrast, a decrease in precipitation of $-0.76 \pm 1.34 \mathrm{~mm} \mathrm{a}^{-1}$ on average during $1960-2013$ was determined from the in situ measurements (Zhang and others,
2019). Based on the CMFD, Longbasaba Glacier receives more than $50 \%$ of its yearly precipitation in August and September, when the mean air temperatures approximately equal to $0^{\circ} \mathrm{C}$, and is therefore likely in the form of rain (Fig. 7c).

Although Longbasaba Glacier is in direct contact with a proglacial lake, a faster decrease in glacier area and length was not observed along with lake expansion over this period (King and others, 2019; Zhang and others, 2019; Luo and others, 2020). The glaciers in the central Himalaya experience their maximum accumulation in summer, so they are more sensitive to climate warming (Fujita and others, 2008; Yao and others, 2012a; Sakai and others, 2015). This is because climate warming directly reduces the amount of solid precipitation (i.e. snow accumulation) and extends the melting period (Bolch and others, 2012). Unfortunately, we did not find a significant correlation between climate change (increases in temperature and decreases in precipitation) and the glacier degradation (decreases in area and surface lowering), even for different lag times of 3-5 years. In the Poiqu River Basin adjacent to Longbasaba Glacier, the surface elevations of the lake-terminating glaciers have decreased at higher mean rates of $-0.65 \pm 0.04 \mathrm{~m} \mathrm{a}^{-1}$ during $1974-2000$ and $-0.80 \pm 0.05$ $\mathrm{m} \mathrm{a}^{-1}$ during 2000-17 (Zhang and others, 2019). These rates are more negative than the values for Longbasaba Glacier and the lake-terminating glaciers in the Himalaya. This releases that 

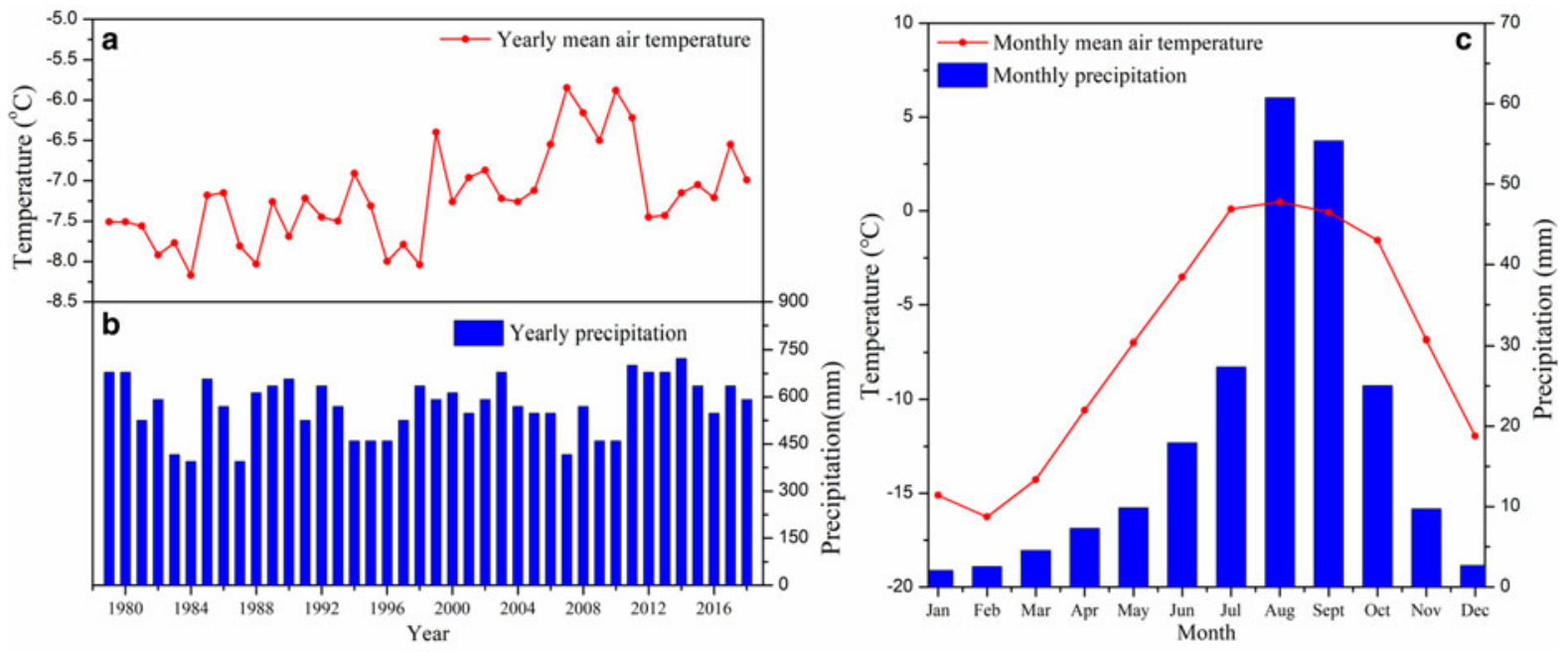

Fig. 7. Yearly and monthly changes in mean air temperature and precipitation in the study area during 1979-2018. The time series of the temperature and precipitation were acquired from the data of the CMFD tiles covering Longbasaba Lake and the tongue of Longbasaba Glacier on the yearly and monthly scales. (a) Changes in yearly mean air temperature from 1979 to 2018. (b) Changes in yearly precipitation from 1979 to 2018. (c) Monthly characteristics of the mean air temperature and precipitation based on the daily values from 1979 to 2018.

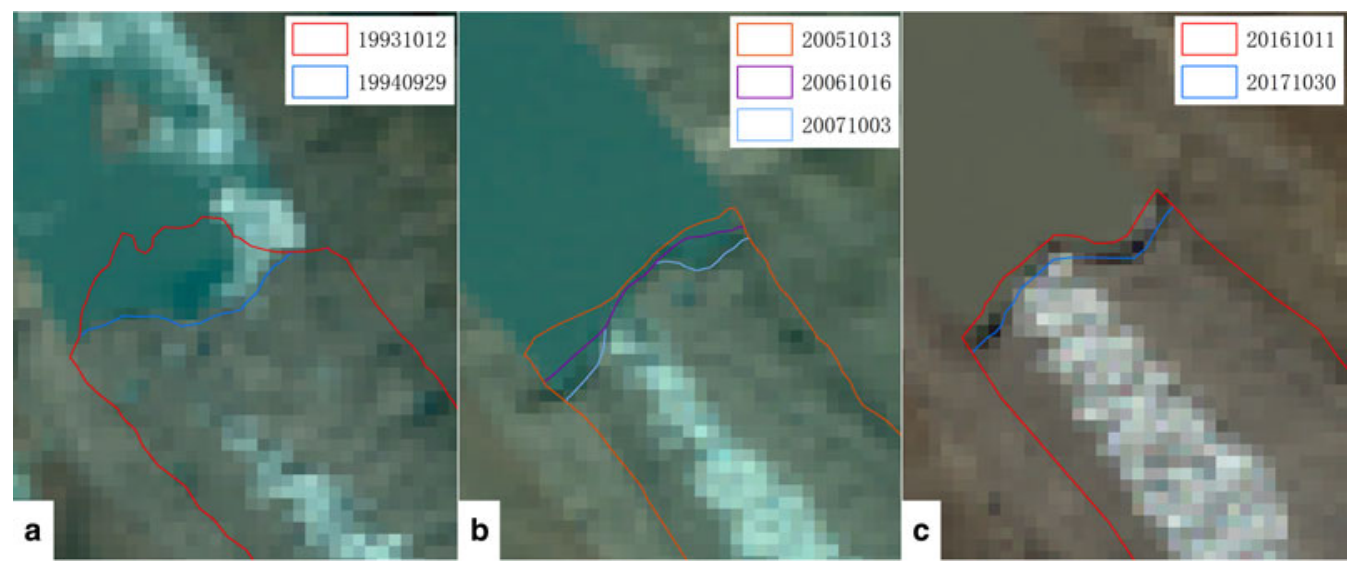

Fig. 8. Three categories representing different patterns of terminus retreat of Longbasaba Glacier during specific periods. The background maps are Landsat TM IOLI images taken in 1994, 2007 and 2017, respectively. (a) Retreat mainly occurred at the center of the glacier terminus during 1993-94. (b) Retreat mainly occurred on the flanks of the glacier terminus during 2005-07. (c) Homogeneous retreat of the glacier terminus at the center and on the flanks during $2016-17$.

the glacier shrinkage was controlled by other contributing mechanisms and more detailed models at the glacier-scale are needed.

It should be noted that heterogeneous retreats of the glacier terminus occurred at the center and flanks before 2008 (Fig. 3). During 1993-94, 2000-01 and 2003-04, the center of the glacier terminus experienced a greater retreat than the flanks (Fig. 8a). This is most likely caused by huge or numerous ice calving events from the central terminus considering the magnitude of the area decrease and the crevasses on the glacier terminus (Fig. 1b). When the area decreases mainly occurred at the flanks (Fig. 8b), the glacier length decreased slightly with a medium decrease in glacier area, such as during 1990-91, 1999-2000, 2001-03 and 2005-07. These specific patterns of glacier recession leaded to variable mass losses from glacier terminus prior to 2008, while the homogeneous retreat of the center and flanks caused a less variation for the glacier recession during 2008-18 (Figs 3 and $8 \mathrm{c}$ ). The occurrence of both ice calving and subaqueous melt could exacerbate the surface lowering at the glacier terminus, and also the increased proglacial lake depth could enhance calving fluxes and glacier flow rates (Benn and others, 2007; Truffer and Motyka, 2016; King and others, 2019; Tsutaki and others, 2019).
On the contrary, the mass loss could drive the decrease in the glacier flow velocity (Dehecq and others, 2018), resulting in lower calving rates. For Longbasaba Glacier, the amplified rate of terminus surface lowering would play a role on the decrease of flow velocities and the occurrence of ice calving during the last decade. Overall, for glaciers in direct contact with proglacial lakes, specific changes in area and ice mass are controlled by a complicated combination of processes and diverse local topographic conditions (Fujita and Sakai, 2014; Immerzeel and others, 2014; King and others, 2017; Song and others, 2017; Zhang and others, 2019). To assess the complex processes of the changes in glacier area and mass budget for the lake-terminating glaciers, detailed dynamic studies at the glacier-scale of the mass and energy interaction between glaciers and lakes are urgently needed in the future.

\section{Expansion of the proglacial lake}

Throughout the Himalaya, the surface area of proglacial lakes has expanded by $2.1 \% \mathrm{a}^{-1}$ during $1990-2015$, and the mean expansion rate increased from $1.8 \% \mathrm{a}^{-1}$ during $1990-2010$ to $2.3 \% \mathrm{a}^{-1}$ during 2010-15 (Nie and others, 2017). The fastest 
growth percentage occurred in the central Himalaya. For the proglacial lakes in contact with debris-covered glacier tongues, the surface area increased by a mean of $2.6 \% \mathrm{a}^{-1}$ during 2000-14, with a lower expansion rate for lakes in contact with clean-ice glacier terminus (Song and others, 2017). For the 42 morainedammed glacial lakes on the northern slope of the central and eastern Himalaya, the total area has expanded by $43.6 \%$ during 1990-2015 (Begam and others, 2019). The areas of the glacier lakes in the Poiqu River Basin expanded at a mean rate of $2.2 \%$ $\mathrm{a}^{-1}$ during 1964-2017, and the mean growth rate decreased from $2.4 \% \mathrm{a}^{-1}$ during $1964-2010$ to $0.2 \% \mathrm{a}^{-1}$ during $2010-17$ (Zhang and others, 2019). For the two fastest growing proglacial lakes in the Nepal Himalaya, the lake areas showed an accelerating growth rate during 1975-2017, with mean expansion rates of $0.03 \mathrm{~km}^{2} \mathrm{a}^{-1}$ for Imja Lake and $0.04 \mathrm{~km}^{2} \mathrm{a}^{-1}$ for Lower Barun Lake (Haritashya and others, 2018).

A higher expansion percentage was found for Longbasaba Lake than for the other proglacial lakes throughout the Himalaya and the adjacent basins/regions (Nie and others, 2017; Zhang and others, 2019). During 1978-2005, the surface area of Longbasaba Lake increased at a mean rate of $5.2 \% \mathrm{a}^{-1}$, but which is less than the growth rate of $7.2 \% \mathrm{a}^{-1}$ for the adjacent Pida Lake with an area of $0.97 \mathrm{~km}^{2}$ in 2005 (Wang and others, 2008). For Longbasaba Lake, the mean expansion rate of $0.028 \pm 0.001 \mathrm{~km}^{2} \mathrm{a}^{-1}\left(8.3 \% \mathrm{a}^{-1}\right)$ was determined for 1977-2009, and the changes during 2000-09 were twice as large as the values during 1977-80 (Yao and others, 2012b). In this study, a higher mean increase rate of $0.032 \pm 0.001 \mathrm{~km}^{2} \mathrm{a}^{-1}$, but a lower percentage $\left(5.3 \% \mathrm{a}^{-1}\right)$, was determined for $1988-2009$. This growth percentage decreased to $3.4 \% \mathrm{a}^{-1}$ with a more mean increase rate of $0.035 \pm$ $0.002 \mathrm{~km}^{2} \mathrm{a}^{-1}$ during the last decade. Generally, the proglacial lakes initially formed with a small surface area, and then, they grew rapidly according to the front retreat of their host glaciers, which indicates that most of the expansion occurred at the beginning of lake growth (Wang and others, 2008; Yao and others, 2012b; Haritashya and others, 2018).

For Longbasaba Lake, the water inflow due to the degradation of its host glacier was predominantly contributed by the glacier surface lowering, with a decrease during the last few decades. However, the mass loss from glacier terminus dynamics, including ice flow and frontal retreat, has doubled from 1988-2000 to 2000-18. This water budget is manifested by ice melting and calving from the glacier front. Although the occurrence and scale of ice calving has decreased over the most recent decade, the hazard risk of this proglacial lake could be promoted by the increase of mass loss contribution from terminus motions, the water volume expansion and the continuous deterioration of the permafrost in the moraine dam.

Proglacial lakes exacerbate recession of their host glaciers (King and others, 2019), which results in continued retreat of the glacier terminus. The bed elevation at the glacier front rises as the glacier terminus retreats. Once the bed elevation at the glacier front is equal to the lake water level in the future, the proglacial lake will physically detach from its host glacier and change to an unconnected glacial lake (Sakai and others, 2009; Haritashya and others, 2018; Luo and others, 2020; Watson and others, 2020). A continued retreat of Longbasaba Glacier was observed over the past three decades, and this retreat is expected to continue into the future. The subsequent retreat of the glacier terminus on the up-valley side of the proglacial lake would allow Longbasaba Glacier to become a land-terminating glacier. With the assumption that the glacier front retreat at the mean rate during 2008-18 $\left(58 \pm 15 \mathrm{~m} \mathrm{a}^{-1}\right)$ and the lake water level remains stable in the future, it should take approximately another four decades for the glacier terminus to separate from the lake, and the potential maximum surface area for the lake is $\sim 2.623 \pm$
$0.169 \mathrm{~km}^{2}$ (Fig. 6b). The potential maximum water volume is $0.110 \pm 0.008 \mathrm{~km}^{3}$, with the mean and maximum depths of 48.8 \pm 5.3 and $102.3 \pm 5.3 \mathrm{~m}$. It reveals expansion percentages of $64.9 \%$ in area and $32.4 \%$ in water volume relative to the corresponding values in 2018 .

\section{Conclusions}

This study investigated the evolution of the recession of Longbasaba Glacier and the related expansion of the proglacial lake over the period of 1988-2018, while the mass contributions from glacier degradation to the water volume of the proglacial lake were assessed. The recession rate of Longbasaba Glacier has increased slightly during 1988-2019, but slowed down during the last decade. The glacier recession was more variable prior to 2008 than during 2000-18. The mean surface-lowering rate decreased between 1975-2000 and 2000-16. The mean areal shrinkage rate was lower than those of other glaciers throughout the Himalaya, whereas the glacier surface lowering rate was higher than the regional average in the decades before 2000 but lower during $2000-16$. The extent and volume of Longbasaba Lake increased during 1988-2018, with expansion rates decreasing over the last decade. The water inflow was predominantly contributed by mass wastage due to glacier surface lowering. The mass contribution from glacier degradation has decreased between $1988-2000$ and $2000-18$. Nevertheless, glacier terminus retreat and flow contributed to an increasing amount of mass loss, which could increase the hazard risk of the proglacial lake. In the future, Longbasaba Lake may reach a maximum water volume of $0.110 \pm 0.008 \mathrm{~km}^{3}$ after four decades, assuming the retreat rate of the host glacier remains stable.

Supplementary material. The supplementary material for this article can be found at https://doi.org/10.1017/jog.2020.119.

Data. The Landsat TM\ETM + OLI images are available from the USGS (https://www.usgs.gov/land-resources/nli/landsat/landsat-level-1-processingdetails). The High Mountain Asia Gridded Glacier Thickness Changes from Multi-sensor DEMs, Version 1 is available from the National Snow and Ice Data Center (NSIDC) (https://nsidc.org/data/hma_glacier_dh). The free software module Co-registration of Optically Sensed Images and Correlation (COSI-Corr) is available from the Caltech Tectonics Observatory (TO) (http://www.tectonics.caltech.edu/slip_history/spot_coseis/download_software. html). The consensus estimates of the ice thickness and the glacier surface DEMs are available from ETH Zurich (https:/doi.org/10.3929/ethz-b000315707). The China Meteorological Forcing Dataset (CMFD) is released by the National Tibetan Plateau Data Center (http://data.tpdc.ac.cn/en/data/ 8028b944-daaa-4511-8769-965612652c49/). The in situ echo sounder points with positions and water depths for Longbasaba Lake can be obtained from Junfeng Wei upon request.

Acknowledgements. This work was funded by the fundamental program of the National Natural Science Foundation of China (grant no. 41701061) and the research project of Hunan University of Science and Technology (grant no. E51669). This research was also supported by the fundamental program of the National Natural Science Foundation of China (grant no. 41761144075 and 41771075), and the National Key Research and Development Program of China (grant no. 2018YFE0100100). We are grateful to the California Institute of Technology (CIT) for providing the not-for-profit institution with the COSI-Corr software. We thank the two anonymous reviewers, Hester Jiskoot (Chief editor) and Dan Shugar (Scientific editor) for their contributions to the final version of this paper.

\section{References}

Andreassen LM, Elvehøy H, Kjøllmoen B and Belart JM (2020) Glacier change in Norway since the 1960s - an overview of mass balance, area, length and surface elevation changes. Journal of Glaciology 66(256), 313328. doi: $10.1017 /$ jog.2020.10. 
Ayoub F, Leprince S and Avouac JP (2017) User's guide to COSI-CORR co-registration of optically sensed images and correlation. California Institute of Technology. doi:10.1109/IGARSS.2007.4423207.

Azam MF and 5 others (2018) Review of the status and mass changes of Himalayan Karakoram glaciers. Journal of Glaciology 64(243), 61-74. doi: 10.1017/jog.2017.86.

Begam S and Sen D (2019) Mapping of moraine dammed glacial lakes and assessment of their areal changes in the central and eastern Himalayas using satellite data. Journal of Mountain Science 16(1), 77-94. doi:10. 1007/s11629-018-5023-1.

Bengtsson L (1980) Evaporation from a snow cover. Nordic Hydrology 11, 221-234. doi:10.2166/nh.1980.017.

Benn DI, Warren CR and Mottram RH (2007) Calving processes and the dynamics of calving glaciers. Earth-Science Reviews 82, 143-179. doi:10. 1016/j.earscirev.2007.02.002.

Bolch T and 7 others (2010) A glacier inventory for the western Nyainqentanglha Range and the Nam Co Basin, Tibet, and glacier changes 1976-2009. The Cryosphere 4, 419-433. doi: 10.5194/tc-4-419-2010.

Bolch T and 11 others (2012) The state and fate of Himalayan glaciers. Science (New York, N.Y.) 336, 310-314. doi: 10.1126/science.1215828.

Brock BW and 5 others (2010) Meteorology and surface energy fluxes in the 2005-2007 ablation seasons at the Miage debris-covered glacier, Mont Blanc Massif, Italian Alps. Journal of Geophysical Research 115, D09106. doi: 10. 1029/2009JD013224.

Brun F and 6 others (2019) Heterogeneous influence of glacier morphology on the mass balance variability in High Mountain Asia. Journal of Geophysical Research: Earth Surface 124(6), 1331-1345. doi: 10.1029/ 2018 ff004838.

Brun F, Berthier E, Wagnon P, Kääb A and Treichler D (2017) A spatially resolved estimate of High Mountain Asia glacier mass balances from 2000 to 2016. Nature Geoscience 10(9), 668. doi:10.1038/NGEO2999.

Carrivick JL and Tweed FS (2013) Proglacial lakes: character, behaviour and geological importance. Quaternary Science Reviews 78, 34-52. doi:10.1016/j. quascirev.2013.07.028.

Carrivick JL and Tweed FS (2016) A global assessment of the societal impacts of glacier outburst floods. Global and Planetary Change 144, 1-16. doi:10. 1016/.j.gloplacha.2016.07.001k.

Chinese National Standard (2008) Compilation specifications for national fundamental scale maps. Part 1: Compilation specifications for 1:25 000/ 1:50 000/1:100 000 topographic maps, GB/T 12343.1-2008, General Administration of Quality Supervision, Inspection and Quarantine, Beijing, China.

Cogley JG (2016) Glacier shrinkage across High Mountain Asia. Annals of Glaciology 57(71), 41-49. doi:10.3189/2016AoG71A040.

Copland L, Sharp MJ, Nienow P and Bingham G (2003) The distribution of basal motion beneath a High Arctic polythermal glacier. Journal of Glaciology 49(166), 407-414. doi:10.3189/172756503781830511.

Dehecq A and 9 others (2018) Twenty-first century glacier slowdown driven by mass loss in High Mountain Asia. Nature Geoscience 12, 22-27. doi: 10. 1038/s41561-018-0271-9.

Farinotti D and 6 others (2019) A consensus estimate for the ice thickness distribution of all glaciers on Earth. Nature Geoscience 12(3), 168-173. doi:10.1038/s41561-019-0300-3.

Fujita K and Sakai A (2014) Modelling runoff from a Himalayan debriscovered glacier. Hydrology and Earth System Sciences 18(7), 2679-2694. doi:10.5194/hess-18-2679-2014.

Fujita K, Suzuki R, Nuimura T and Sakai A (2008) Performance of ASTER and SRTM DEMs, and their potential for assessing glacial lakes in the Lunana region, Bhutan Himalaya. Journal of Glaciology 54(185), 220-228. doi:10.3189/002214308784886162.

Gantayat P, Kulkarni AV and Srinivasan J (2014) Estimation of ice thickness using surface velocities and slope: case study at Gangotri Glacier, India. Journal of Glaciology 60(220), 277-282. doi:10.3189/2014JoG13J078.

Gardelle J, Berthier E, Arnaud Y and Kääb A (2013) Region-wide glacier mass balances over the Pamir - Karakoram - Himalaya during 19992011. The Cryosphere 7, 1263-1286. doi:10.5194/tc-7-1263-2013.

Guo W and 10 others (2015) The second Chinese glacier inventory: data, methods, and results. Journal of Glaciology 61(226), 1-16. doi: 10.3189/ 2015JoG14J209.

Guo W, Liu S, Wei J and Bao W (2013) The 2008/09 surge of central Yulinchuan glacier, northern Tibetan Plateau, as monitored by remote sensing. Annals of Glaciology 54(63), 299-310. doi:10.1007/s11629-018-5011-5.
Haritashya UK and 6 others (2018) Evolution and controls of large glacial lakes in the Nepal Himalaya. Remote Sensing 10(5), 798. doi: 10.3390/ rs10050798.

Harper JT and 5 others (2001) Spatial variability in the flow of a valley glacier: deformation of a large array of boreholes. Journal of Geophysical Research 106(B5), 8547-8562. doi: 10.1029/2000JB900440.

He J and 6 others Y (2020) The first high-resolution meteorological forcing dataset for land process studies over China. Scientific Data 7, 25. doi: 10. 1038/s41597-020-0369-y.

Huss M (2013) Density assumptions for converting geodetic glacier volume change to mass change. The Cryosphere 7, 877-887. doi:10.5194/tc-7-8772013

Hutchinson MF (2004) ANUDEM version 5.1 User Guide. Centre for Resource and Environmental Studies, Australian National University, Canberra.

Immerzeel WW and 6 others (2014) High-resolution monitoring of Himalayan glacier dynamics using unmanned aerial vehicles. Remote Sensing of Environment 150, 93-103. doi: j.rse.2014.04.025.

IPCC (2018) Summary for Policymakers. In: Global Warming of $1.5^{\circ} \mathrm{C}$. An IPCC Special Report on the impacts of global warming of $1.5^{\circ} \mathrm{C}$ above pre-industrial levels and related global greenhouse gas emission pathways, in the context of strengthening the global response to the threat of climate change, sustainable development, and efforts to eradicate poverty. World Meteorological Organization, Geneva, Switzerland.

Kääb A, Berthier E, Nuth C, Gardelle J and Arnaud Y (2012) Contrasting patterns of early twenty-first-century glacier mass change in the Himalayas. Nature 488, 495-498. doi:10.1038/nature11324.

Kang E, Cheng G, Lan Y and Jin H (1999) A model for simulating the response of runoff from the mountainous watersheds of inland river basins in the arid area of northwest China to climatic changes. Science in China Series D: Earth Sciences 42(1), 52-63. doi:10.1007/BF02878853.

King O, Bhattacharya A, Bhambri R and Bolch T (2019) Glacial lakes exacerbate Himalayan glacier mass loss. Scientific Reports 9(1), 18145. doi:10. 1038/s41598-019-53733-x.

King O, Quincey DJ, Carrivick JL and Rowan AV (2017) Spatial variability in mass loss of glaciers in the Everest region, central Himalayas, between 2000 and 2015. The Cryosphere 11, 407-426. doi:10.5194/tc-11-407-2017.

Lei Y and 5 others (2013) Coherent lake growth on the central Tibetan Plateau since the 1970s: characterization and attribution. Journal of Hydrology 483, 61-67. doi: 10.1016/j.jhydrol.2013.01.003.

Leprince S, Barbot S, Ayoub F and Avouac JP (2007) Automatic and precise orthorectification, coregistration, and subpixel correlation of satellite images, application to ground deformation measurements. IEEE Transactions on Geoscience and Remote Sensing 45(6), 1529-1558. doi:10. $1109 /$ tgrs.2006.888937.

Li $\mathbf{J}$ and 5 others (2014) Investigating mountain glacier motion with the method of SAR intensity-tracking: removal of topographic effects and analysis of the dynamic patterns. Earth-Science Reviews 138, 179-195. doi: 10.1016/j.earscirev.2014.08.016.

Liu Q and 6 others (2010) Recent shrinkage and hydrological response of Hailuogou glacier, a monsoon temperate glacier on the east slope of Mount Gongga, China. Journal of Glaciology 56(196), 215-224. doi: 10. $3189 / 002214310791968520$.

Liu Q and 6 others (2020) Interannual flow dynamics driven by frontal retreat of a lake-terminating glacier in the Chinese Central Himalaya. Earth and Planetary Science Letters 546, 116450. doi: 10.1016/j.epsl.2020. 116450.

Liu Y, Hou S, Wang Y and Song L (2009) Distribution of borehole temperature at four high-altitude alpine glaciers in Central Asia. Journal of Mountain Science 6, 221-227. doi:10.1007/s11629-009-0254-9.

Luo W, Zhang G, Chen W and Xu F (2020) Response of glacial lakes to glacier and climate changes in the western Nyainqentanglha range. Science of The Total Environment 735, 139607. doi:10.1016/j.scitotenv.2020.139607.

Maurer J, Rupper S and Schaefer J (2018) High Mountain Asia Gridded Glacier Thickness Change from Multi-Sensor DEMs, Version 1. Boulder, Colorado USA. NASA National Snow and Ice Data Center Distributed Active Archive Center. doi: 10.5067/GGGSQ06ZR0R8.

Miles KE and 6 others (2018) Polythermal structure of a Himalayan debriscovered glacier revealed by borehole thermometry. Scientific Reports $\mathbf{8}(1)$, 16825. doi: $10.1038 / \mathrm{s} 41598-018-34327-5$.

Nie Y and 6 others (2017) A regional-scale assessment of Himalayan glacial lake changes using satellite observations from 1990 to 2015. Remote Sensing of Environment 189, 1-13. doi: 10.1016/j.rse.2016.11.008. 
Nie Y and 5 others (2018) An inventory of historical glacial lake outburst floods in the Himalayas based on remote sensing observations and geomorphological analysis. Geomorphology 308, 91-106. doi: 10.1016/j.geomorph. 2018.02.002.

Paterson WSB (1994) The Physics of Glaciers. Oxford, UK: Pergamon.

Perutz MF (1949) Direct measurement of the velocity distribution in a vertical profile through a glacier. Journal of Glaciology 1(5), 382-283. doi:10.3189/ 002214349793702593

Richardson SD and Reynolds JM (2000) An overview of glacial hazards in the Himalayas. Quaternary International 65-66, 31-47. doi:10.1016/S1040-6182 (99)00035-X.

Ruiz L, Berthier E, Masiokas M, Pitte P and Villalba R (2015) First surface velocity maps for glaciers of Monte Tronador, North Patagonian Andes, derived from sequential Pléiades satellite images. Journal of Glaciology $\mathbf{6 1}$ (229), 908-922. doi:10.3189/2015JoG14J134.

Sakai A and 5 others (2015) Climate regime of Asian glaciers revealed by GAMDAM glacier inventory. The Cryosphere 9, 865-880. doi: 10.5194/ tc-9-865-2015.

Sakai A, Nishimura K, Kadota T and Takeuchi N (2009) Onset of calving at supraglacial lakes on debris-covered glaciers of the Nepal Himalaya. Journal of Glaciology 55(193), 909-917. doi:10.3189/00221430979015255.

Singha P and Bengtsson $\mathbf{L}$ (2005) Impact of warmer climate on melt and evaporation for the rainfed, snowfed and glacierfed basins in the Himalayan region. Journal of Hydrology 300, 140-154. doi:10.1016/j.jhydrol.2004.06.005.

Song C and 5 others (2017) Heterogeneous glacial lake changes and links of lake expansions to the rapid thinning of adjacent glacier termini in the Himalayas. Geomorphology 280, 30-38. doi: 10.1016/j.geomorph.2016.12.002.

Treichler D, Kääb A, Salzmann N and Xu C (2019) Recent glacier and lake changes in High Mountain Asia and their relation to precipitation changes. The Cryosphere 13(11), 2977-3005. doi:10.5194/tc-13-2977-2019.

Truffer M and Motyka RJ (2016) Where glaciers meet water: subaqueous melt and its relevance to glaciers in various settings. Reviews of Geophysics 54, 220-239. doi:10.1002/2015RG000494.

Tsutaki S and 6 others (2019) Contrasting thinning patterns between lakeand land-terminating glaciers in the Bhutanese Himalaya. The Cryosphere 13, 2733-2750. doi: 10.5194/tc-13-2733-2019.

Wang $\mathbf{X}$ and 8 others (2018) Monitoring and simulation of hydrothermal conditions indicating the deteriorating stability of a perennially frozen moraine dam in the Himalayas. Journal of Glaciology 64(245), 407-416. doi: 10.1017/jog.2018.38.

Wang X, Liu S, Guo W and Xu J (2008) Assessment and simulation of glacier lake outburst floods for Longbasaba and Pida Lakes, China. Mountain Research and Development 28, 310-317. doi:10.1659/mrd.0894.

Wang X, Liu Q, Liu S, Wei J and Jiang Z (2016) Heterogeneity of glacial lake expansion and its contrasting signals with climate change in Tarim Basin, Central Asia. Environmental Earth Sciences 75, 696. doi:10.1007/s12665-016-5498-4.
Wang S, Qin D and Xiao C (2015) Moraine-dammed lake distribution and outburst flood risk in the Chinese Himalaya. Journal of Glaciology $6 \mathbf{1}$ (225), 115-126. doi:10.3189/2015JoG14J097.

Watson CS and 5 others (2020) Mass loss from calving in Himalayan proglacial lakes. Frontiers in Earth Science 7, 342. doi: 10.3389/feart.2019. 00342.

Wei J and 5 others (2015) Changes in glacier volume in the north bank of the Bangong Co Basin from 1968 to 2007 based on historical topographic maps, SRTM, and ASTER stereo images. Arctic Antarctic and Alpine Research 47 (2), 155-165. doi: 10.1657/AAAR00C-13-129.

Wu K and 5 others (2018) Recent glacier mass balance and area changes in the Kangri Karpo Mountains from DEMs and glacier inventories. The Cryosphere 12, 103-121. doi: 10.5194/tc-12-103-2018.

Wu K, Liu S, Jiang Z, Xu J and Wei J (2019) Glacier mass balance over the central Nyainqentanglha Range during recent decades derived from remote-sensing data. Journal of Glaciology 65(251), 422-439. doi:10.1017/jog.2019.20.

Xu D (1988) Characteristics of debris flow caused by outburst of glacial lake in Boqu River, Xizang, China, 1981. GeoJournal 17(4), 569-580. doi:10.1007/ bf00209443.

Yamada T and Sharma CK (1993) Glacier lakes and outburst floods in the Nepal Himalaya. IAHS Publication 218, 319-330.

Yang K and He J (2018) China Meteorological forcing dataset (1979-2018). National Tibetan Plateau Data Center. doi:10.11888/AtmosphericPhysics. tpe.249369.file.

Yao T and 14 others (2012a) Different glacier status with atmospheric circulations in Tibetan Plateau and surroundings. Nature Climate Change 2(9), 663-667. doi: 10.1038/NCLIMATE1580.

Yao X, Liu S, Sun M, Wei J and Guo W (2012b) Volume calculation and analysis of the changes in moraine-dammed lakes in the north Himalaya: a case study of Longbasaba lake. Journal of Glaciology 58(210), 753-760. doi:10. 3189/2012JoG11J048.

Zemp M and 14 others (2019) Global glacier mass changes and their contributions to sea-level rise from 1961 to 2016 . Nature 568(7752), 382-386. doi: 10.1038/s41586-019-1071-0

Zhang G and 13 others (2017) Lake volume and groundwater storage variations in Tibetan Plateau's endorheic basin. Geophysical Research Letters 44(11), 5550-5560. doi: 10.1002/2017GL073773.

Zhang G and 5 others (2019) Glacial lake evolution and glacier-lake interactions in the Poiqu River basin, central Himalaya, 1964-2017. Journal of Glaciology 65(251), 347-365. doi: 10.1017/jog.2019.13.

Zhang Y, Hirabayashi Y and Liu S (2012) Catchment-scale reconstruction of glacier mass balance using observations and global climate data: case study of the Hailuogou catchment, south-eastern Tibetan Plateau. Journal of Hydrology 444-445, 146-160. doi:10.1016/j.jhydrol. 2012.04.014. 